The International Journal of Engineering and Science (IJES)

|| Volume || 6 || Issue || 7 || Pages || PP 57-60 || 2017 ||

ISSN (e): $2319-1813$ ISSN (p): $2319-1805$

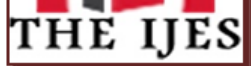

\title{
Geological-Mathematical and Economic Informations in Geological-Economic Study of Mineral Resources
}

\author{
Radule Tosovic \\ University of Belgrade, Faculty of Mining and Geology, Department of Economic Geology \\ Djusina street 7, Belgrad, Serbia,toshovic@yahoo.com, radule.tosovic@rgf.bg.ac.rs \\ Corresponding author: Radule Tosovic
}

\begin{abstract}
-
Different types of information are used in studying the genetic and economic characteristics of mineral resources, including geological and mathematical and economic-mathematical information of particular importance. Geological-mathematical informations and models allow both systematic and complete study on mineral deposits per all elements of a complex genetical model of mineral deposits, and economic-mathematical information according to the geological-economic model of mineral deposits. In the work with genetic studies it is of particular importance to participate in the interpretation of the conditions and the way of becoming, quantification and functional expression of parameters of the ore process and spatial localization of mineral products. In the area of economic studies, they are important for expressing factors and indicators of a geological and economic evaluation, in order to arrive at the final expression of the value of mineral reserves. From a pact economic side it is of particular importance to examine the conditions and economic effects of geological exploration of mineral resources, their exploitation, technological treatment and market valorization in various economic activities and activities.
\end{abstract}

Key words: geological-mathematical information, geological-economic evaluation, mineral deposit, mineral economy.

Date of Submission: 18-07-2017

Date of Publication: 28-07-2017

\section{INTRODUCTION}

Mineral resources and mineral deposits are the basic economic category in the mineral sector and mineral economy of the country [1]. Their geological location, exploration and spatial definition require the necessary investment in a longer period of time, on average from 7 to 10 years. Based on found and established mineral reserves, there must be conditions for their economic viability, which will ensure their return and ensure the creation of additional profit [2].

The final scientific goal of mineral deposit studies is, in fact, explanation of its genesis, namely, in practice, obtaining knowledge on geological aspects that are in function of both mineral ores exploitation and valorization [3]. The basic economic assumption is that the newly established value of found mineral reserves is significantly higher than the total investments invested. Therefore, initial genetic studies represent a key for solving numerous scientific and practical questions. Within contemporary conditions of collected numerous data processing, aimed for creation of adequate genetic and geological-economic model of deposit, different mathematical models proved to be irreplaceable, using geological and economic information create geologicalmathematical and geological-economic models as a basis for further investigations. Creation of quality geological-mathematical and geological-economic models as well as their application are supported by certain aspects representing optimum working conditions for genetic and geological-economic study of mineral deposit $[4,5,6]$.

The problems covered by this research-analytical work are based on the basic assumptions of the mineral economy, economic geology and basic issues of the economic evaluation of mineral resources $[7,8,9,10,11$, $12,13]$, and partly a continuation of the previous author's studios analytical-synthetic, inductive-deductive and systematic study studies in the field of economic geology and mineral economy [14-23], which are realized at the Department of Economic Geology of the Mining and Geological Faculty of the University of Belgrade.

The main goal of this paper is the general review of the place, condition and significance of geologicalmathematical and economic-mathematical information in the appropriate genetic and geological-economic studies of mineral resources, focused ultimately on the definition of mineral reserves and their economic importance, as well as the further successful functioning mineral sector and mineral economy of the country. 


\section{GEOLOGICAL-MATHEMATICAL MODELS IN GENETIC AND GEOLOGICAL-ECONOMIC STUDIES}

A quality genetic model of mineral deposit is a model of ore-bearing process that should encompass, among other things, the following [13, 14, 15]: (a) source of elements/components; (b) mechanism of mobilization and primary concentration of elements/ components; (c) transport of elements/ components; (d) storage and concentration of elements/components; and (e) occurrences supporting formation and spatial distribution of mineral deposit. Each segment to a genetic model can have a special parcial model, the complex interconnection of which result in formation of an integral, multifactor supermodel. Investigation of this complex model when applied, shred more light on the state, condition and evolution of geological environment and ore deposit material, as well as on subsequent application of information, particularly obtained through researches and exploitation. In the continuation of the research process in the subject area, the information and interpretations thus obtained are the starting point for the geological-economic definition of mineral deposit and profit determination, which can be achieved through the commercial exploitation of mineral resources.

Both the complexity of natural processes and polivariation of acting factors heavily aggrevate "mathematical processing" of the tasks to genetic and geological-economic modelling [3]. When recognizing a genetic process, quality information are greatly used, which information, burdened with a subjective approach to estimation and a need for exact investigation, require an adequate form of mathematical description, namely a numerical expression. The moment when qyalitative marks are transformed into quantitative is followed by indispensable application of criteria that provide the best transformation representation and offer the most probable quantitative expression of empirical observation. As highly diverse quality information should be inserted into genetic and geological-economic model, the problem of transformation criterion is very significant. At the present level of knowledge and realized solutions, a unique criterion can harly be presented but partial criteria are applied, being incorporated into adequare mathematical equations and relations. Degree of compatibility for these partial criteria is one among numerous indicators for geological-mathematical model representation.

Geological-mathematical model is, in fact, an apstract analogue to a simplified segment of a deposit model where processes, occurrences, events, geological surfaces, areas, relations between parts etc. are presented by mathematical symbols and connected through particular relations.Such a mathematical model is geologically justified and therefore should be improved, developed and applied in accordance with geological laws on deposits formation and their spatial distribution. During formation of mathematical models, recognition of events, occurrences and processes, has frequently been neglected not fully respecting geological laws. Thus, mathematical and geological models of deposit and the processes they treat, should highly be coorelated, respecting a dominant presentation of geological aspects when geological-mathematical model is concerned. At a later stage of the research, this is reflected in the geological-economic models of mineral deposits. When applying a geological-mathematical model in genetic and geological-economic studies, a particular attention should certainly be paid to essential interactive connection of geological and economic laws, on one hand, and on the other, to adequate changes in a mathematically described model being in accordance with criteria of transformation characteristics [5].

The most important among the observed features of mineral deposits are sellected and separated covering morphology, structure, composition of deposit and condition of inclination, then particularly significant elements association, mineral association, useful component content, namely indicator values for mineral quality, temperature of certain minerals formation, results of isotopic researches etc. In the continuation of the work on the economic definition of mineral deposits are particularly important: market and market conditions, investments, costs, cost price, market price, profit and profitability of mineral resource utilization.

Application of adequare mathematical model depends, regarding data homogeneity within a formed processing group, on degree of their natural processing link, namely whether a random, mutually independent variables or a set of randomly correlated values, or correlated values with noted periodicity are concerned. Therefore, each of the mentioned cases requires consideration of specific geological-genetic and geological-economic link and, application of adequate model in accordance with geological and economic criteria.

The analysis of useful component content, namely a mineral quality indicator required for mathematical modelling, is proceeded by establishment of a mathematical model that is designed for a deposit or geological environment, and based on the concept of elements, later on to be extended. This aspect has proved to be essential as, under conditions of variable geological composition of environment and diverse influence of structural characteristics of geological medium, the domain of accepted model should be greatly modified. Classical indicators to a statistical model (a mean value, dispersion etc.) fail to give a complete image of spatial distribution that otherwise is important for genetic study. 
From genetic point of view, the studies on conditions of mineralization through complex modelling of both heterogeneous systems and equilibrium within the same, are very important. These models are particularly suitable when studying a system's evolution at discrete points throughout development from initial to final equilibrium state. Geological-mathematical models of this type offer great possibilities to establish both the causes and succession of deposition of ore and vein minerals from hydrothermal solutions, for example, as well as the influence of country rocks. When applying these models, we should also bear in mind the compexity of natural systems and limited application of already existing solutions, regarding multidimensional structure of ore-bearing systems that result in economically significant mineralization. Further to this, geologicalmathematical models should adequately be modified, regarding possible fluctuations of ore-bearing processes and heterogeneous environment of their occurrence $[14,15]$.

Application of mathematical quantifiers in quantitative estimation of genetic indicators of mineralization provides interesing data and restricts significantly the possible conclusions, thus representing the first step in formation analysis, complete quantitative estimation and finally in discovery of areas promissing in mineralization.

Investigation of a model relating to numerous deposits of the same genetic and geological-economic type enables creation of a pattern, i.e. a standardize genetic and geological-economic model of a deposit, that incorporates the main characteristics of the relevant genetic type $[18,19,20]$. These models both simplify and optimize the working conditions on a deposit, thus enabling a geologist to recognize, through a standardize genetic and geological-economic model, a wide range of properties of the given genetic type. The main disadvantage is, regarding uniformity of each deposit, that a study of genetic characteristics is specific for each case, and concequently a final model of certain deposit is, in fact, a unique genetic and geological-economic model. Geological-mathematical models, implemented in standardize models, should express the main conceptual elements.

Complexity of genetic and geological-economic study and geological-mathematical and geological-economic modelling accordingly, is particularly evident in both polygene ore deposits, where variable element concentrations result from relatively a wide diapason of changes in physico-chemical parameters, and convergent deposits as well as in the same or similar deposits formed during different geological processes. In the part dealing with geological-economical studies, mineral deposits are of particular importance, which contain more mineral raw materials or more useful components in mineral raw materials. In this case, a more complex economic analysis must be carried out, which is related to the consideration of market conditions and the method of complex exploitation of mineral deposits and mineral resources. In this way, better economic effects are achieved and contributes to increasing profits from complete geological, mining and technological activities on the exploitation of the subject mineral raw materials from mineral deposit.

\section{CONCLUSION}

Within modern genetic and geological-economic studies on mineral deposits, a particular importance has been given to utilization of adequate geological-mathematical and geological-economic models resulting from application of mathematical methods to a set of geological and economic information and respecting geological and economic laws. Parcial models can be created per each segment of the considered universal five-element genetic and geological-economic model, the complex connection of which results in formation of a genetic geological-mathematical model and a special geological-economic model. Application of these models is supported by particular aspects that should be taken into account, among which the following are most important:

(a) Complex natural processes and multivariation of acting factors heavily aggrevate "mathematical processing" of genetic and geological-economic modelling.

(b) The moment when qyalitative features are transformed into quantitative, is followed, due to requiremnts of exact expressing and adequate form of mathematical description, by indispensable application of criteria that provide the best represented transformation and most probable quantitative expression of empirical observation.

(c) Recognition of events, occurrences and processes from geological-mathematical and geological-economic aspect is indispensable and accordingly geological and economic laws should be highly respected. Considered from aspect of application it means that a mathematical and a geological and geologicaleconomic model of deposit should be maximally coorelated, as well as the processes. An interactive connection should exist between geological and economic laws and adequate mathematical description of model, in accordance with transformation criteria for features.

(d) As a formed set to be processed consists of heterogeneous data, differentiating in their natural processing links, it is necessary to consider, first and foremost, their geological-genetic and geological-economic link and apply adequate model processing and interpretation in accordance with geological and economic criteria. 
Majority of structure within interpretated models is based on the concept of elementarity that, later on, can be extended. Bearing in mind variable geological composition of environment as well as the influence of structural elements, the applied model should be flexible and open to additional geological-economic modifications.

Geological-mathematical models within a standardize genetic and geological-economic models should express the main conceptual elements.

Apart from scientific contribution, geological-matematical models should provide, within genetic and geological-economic study of mineral deposits, a more economic successful and profitable production in mineral deposits as the main sources in supplying economy with high quality mineral materials.

\section{REFERENCES}

[1] Tosovic R., Mineral Sector and Mineral Economy as the Basis of Socio-economic Development Countries, V. International scientific conference on economic development and standard of living, EDASOL 2016, Economic development and Standard of living, Pan-european University Apeiron, pp. 60-61, Banja Luka, 2016.

[2] Tosovic R., Expert Economic Evaluation of Mineral Reserves in Modern Conditions of Transition of Mineral Economics, New Economist, Journal of Economic Theory and Practice, Faculty of Business Economics Bijeljina, University of East Sarajevo, Year X, Number 20, pp. 87-96, Bijeljina, 2016 (in Serbian).

[3] Tosovic R., Some aspects of Application of Geolocical-Mathematical models in Genetic Study of Mineral Deposits, The VI-th International Symposium on Application of Mathematical Methods and Computers in Minig, Geology and Metallurgy, Prague, Czech Republic, MA-19, 72-75, Prague, 1997.

[4] Tosovic R., General Review of the genetic and geological-economic modeling of the mineral deposits of serbia, International Journal of Research - Granthaalayah, Vol. 4, No. 6, pp. 38 - 45, 2016.

[5] Tosovic R., A research Function of Partial and Integral Genetic Models of the Mineral resource, 13th Congress of Geologists of Yugoslavia, Vol. IV - Mineral Raw Materials, 455-469, Herceg Novi, 1998 (in Serbian).

[6] Stojanovic I., Tosovic R., Serbian Economy in Crisis Conditions at the End of the 20th Century, Global Research Academy, London, Multidisciplinary International Journales, Volume: 01, Number 03 (March), 1-6, London, 2017.

[7] Rudenno V., The Mining Valuation Handbook: Mining and Energy Valuation for Investors and Management, Wrightbooks; 4 edition, 624 pp., 2012.

[8] Rundge I., Mining Economics and Strategy, Society for Mining Metallurgy \& Exploration, 1 edition, Littleton, 316 pp., Colorado, 1998.

[9] Torries F.T., Evaluating Mineral Projects: Applications and Misconceptions, Society for Mining Metallurgy \& Exploration, Littleton, 172 pp., Colorado, 1998.

[10] Wellmer F.W., Dalheimer M., Wagner M., Economic Evaluations in Exploration, Springer; 2nd edition, 264 pp., 2010.

[11] Tosovic R., Expert economic evaluation of mineral resources in the function of environmental protection, International Journal of Research - Granthaalayah, Vol. 4, No. 5, pp. 106 - 114, 2016.

[12] Sirotinskaya S.V., The role of logical - mathematical modeling in studying geological factor of ore formation, Collected abstract of VI Symposium IAGOD, 117-118, Tbilisi, 1982

[13] Janković S., Milovanović D., Economic Geology and Basis of Mineral Resources Economics, RGF, Department of Mineral Exploration, 403 pp., Belgrade, 1985 (in Serbian).

[14] Tosovic R., Geološko-matematički modeli u proučavanju geneze ležišta mineralnih sirovina, XXIII SYMOPIS, 666-669, Beograd, 1996. (in Serbian).

[15] Tosovic R., Geological-Mathematical Models in the Study of the Genesis of Deposits of Mineral Resources, XXIII SYMOPIS, 666669, Belgrade, 1996 (in Serbian).

[16] Tosovic R., Functioning of the Mineral Sector in Transition Conditions, Proceedings II of the Mining and Geological Forum with International Participation, Faculty of Mining Prijedor University of Banja Luka, Association of Engineers and Technicians of the Mining, Geological and Metallurgical profession of Republika Srpska, pp. 248-257, Prijedor, 2016 (in Serbian)

[17] Tosovic R., Expert Economic Evaluation of Mineral Resources in Modern Conditions of Transition and Management, Proceeding of 14th ICDQM-2011, Research Center of Dependability and Quality Management DQM, pp. 624-634, Belgrade, 2011.

[18] Tosovic R., Geological-economical Modeling of the Polymmetallic Deposit Rudnik, Department of Economic Geology, Faculty of Mining and Geology, University of Belgrade, Special. Izd. Br. 8, 226 pp., Belgrade, 2006. (in Serbian with English summary)

[19] Tosovic R., Milovanović D., (2008), The Function of Economic Evaluation in Management of Mineral Resources. 1st Symposium Nature Conservation in Serbia, The Book of Abstracts, Institute for nature conservation of Serbia, pp. 133-134, Novi Sad.

[20] Tosovic R., Milovanović D., (2007), Manager Functions in Management of Mineral Resources, Proceeding of 10th DQM-2007, pp. 850-858, Beograd.

[21] Tosovic R., Business Decision Making and Efficiency in the Allocation of Production Resources in Sustainable Mineral Sector, International Scientific Conference on Objectives of Sustainable Development in the Third Millennium, Book od abstracts, 64-65, Belgrade, 2017.

[22] Tosovic R., Milovanović D., Economic Evaluation and Cash Flow of Investment Project in Economics of Mineral Resources, Tehnika, vol. 60, br. 2, str. 11-18, Beograd, 2009.

[23] Tosovic R., Dasic P., Ristovic I., Sustainable Use of Metallic Mineral Resources of Serbia from An Environmental Perspective, Environmental engineering and management journal, vol. 15 no. 9, pp. 2075-2084, 2016.

Radule Tosovic . "Geological-Mathematical and Economic Informations in GeologicalEconomic Study of Mineral Resources." The International Journal of Engineering and Science (IJES) 6.7 (2017): 57-60. 